\title{
PENINGKATAN KOMPETENSI TENAGA PENDIDIK TERHADAP PRESTASI BELAJAR SISWA DI SMA MUHAMMADIYAH 1 TAMAN
}

\author{
Erna Mufida \& Hidayatullah \\ Universitas Muhammadiyah Sidoarjo \\ ernamufida75@gmail.com,hidayatullah@umsida.ac.id
}

\begin{abstract}
This research is based on the importance of the role of educators in optimizing student achievement in terms of knowledge or cognitive aspects, attitudes or affective aspects and skills or psychomotor aspects. Therefore, this study aims to describe the effect of increasing the competence of teachers on student achievement at SMA Mubammadiyah 1 Taman. The research method used is qualitative research with a phenomenological approach according to the data and facts found in the field directly not the result of presumptions or assumptions. The research was conducted at SMA Mubammadiyah 1 Taman where in the odd semester the student achievement was mostly still below the average parallel score for class XI and XII. Based on that, this school tried to improve the competence of its teaching staff including pedagogical competence, personality competence, social competence, and professional competence through training, habituation of positive things, deliberation and mentoring. Along with the increase in the competence of the teaching staff, it can be seen that student achievement in the even semester has also increased where students whose scores are above the average grade in class X increase by $7 \%$, class XI increases by $12 \%$ and class XII increases by $11 \%$. The conclusion of this study is that the improvement of the competence of the teaching staff includes pedagogical competence, personal competence, social competence and professional competence are closely related to the improvement of student achievement.
\end{abstract}

Keywords : Educators Competency, Student Achievement

\begin{abstract}
Abstrak : Penelitian ini dilandasi oleh pentingnya peran tenaga pendidik dalam mengoptimalkan prestasi belajar siswa baik dari aspek pengetahuan atau kognitif, aspek sikap atau afektif dan aspek keterampilan atau psikomotorik. Oleh karena itu penelitian ini bertujuan untuk mendeskripsikan pengaruh peningkatan kompetensi tenaga pendidik terhadap prestasi belajar siswa di SMA Muhammadiyah 1 Taman. Metode penelitian yang digunakan adalah penelitian kualitatif dengan pendekatan fenomenologis sesuai data dan fakta yang ditemukan di lapangan secara langsung bukan hasil dari praduga atau asumsi. Penelitian dilakukan di SMA Muhammadiyah 1 Taman dimana pada semester ganjil prestasi belajar siswa sebagian besar masih di bawah rata-rata nilai parallel untuk kelas XI dan XII. Berdasarkan hal tersebut sekolah berusaha untuk meningkatkan kompetensi tenaga pendidiknya meliputi kompetensi pedagogik, kompetensi kepribadian, kompetensi sosial, serta kompetensi profesional melalui pelatihan, pembiasaan hal-hal positif, musyawarah dan pendampingan. Seiring dengan meningkatnya kompetensi tenaga pendidik dapat dilihat bahwa prestasi belajar siswa di semester genap juga mengalami peningkatan dimana siswa yang nilainya di atas nilai rata-rata di kelas X meningkat sebanyak 7\%, kelas XI meningkat
\end{abstract}

Manazhim : Jurnal Manajemen dan Ilmu Pendidikan

Volume 2, Nomor 2, Agustus 2020; 182-191

https://ejournal.stitpn.ac.id/index.php/manazhim 
sebanyak 12\% dan kelas XII meningkat sebanyak $11 \%$. Kesimpulan dari penelitian ini adalah peningkatan kompetensi tenaga pendidik meliputi kompetensi pedagogik, kompetensi kepribadian, kompetensi sosial maupun kompeteni profesional berkaitan erat dengan peningkatan prestasi belajar siswa.

Kata Kunci : Kompetensi Tenaga Pendidik, Prestasi Belajar Siswa

\section{PENDAHULUAN}

Lembaga pendidikan yang berkualitas dapat dilihat dari kompetensi atau kualitas para peserta didiknya. Kompetensi atau kualitas peserta didik ini dapat berupa kualitas dalam kognitif atau pengetahuan, sikap atau afektif dan psikomotorik atau keterampilan. Oleh karena itu perlu adanya penyesuaian dalam proses pembelajaran hingga evaluasinya untuk bisa meliputi ketiga aspek tersebut yang biasa dikenal juga dengan prestasi belajar siswa ${ }^{1}$. Prestasi belajar siswa sendiri merupakan perwujudan dari hasil usaha belajar siswa dalam kegiatan belajar mengajar yang telah dilaksanakan.

Proses pencapaian prestasi belajar siswa dipengaruhi oleh faktor internal maupun faktor eksternal, faktor internal nya bisa berupa kondisi fisiologis dan kondisi psikologis siswa, sedangkan faktor eksternal dapat berupa lingkungan belajar serta tenaga pendidik yang berinteraksi dengan siswa ${ }^{2}$. Kompetensi guru yang baik akan mampu menjadi teladan bagi siswa, mampu membuat siswa untuk bisa aktif, kreatif, inovatif dan berintegritas tinggi di sekolah. Kompetensi guru tersebut meliputi kompetensi pedagogik, kompetensi kepribadian, kompetensi sosial dan kompetensi profesional guru yang diharapkan mampu meningkatan prestasi belajar siswa ${ }^{3}$.

Pentingnya peran dari tenaga pendidik dalam mengarahkan prestasi belajar serta memperbaiki perilaku siswa memerlukan kesiapan dan kompetensi dalam

\footnotetext{
${ }_{1}^{1}$ Asrul, Rusydi Ananda, and Rosinta, Evaluasi Pembajalaran, Ciptapustaka Media, 2014.

2 Widia Hapnita, 'Faktor Internal Dan Eksternal Yang Dominan Mempengaruhi Hasil Belajar Menggambar Dengan Perangkat Lunak Siswa Kelas Xi Teknik Gambar Bangunan Smk N 1 Padang Tahun 2016/2017', CIVED (Journal of Civil Engineering and Vocational Education), 5.1 (2018) <https://doi.org/10.24036/cived.v5i1.9941>.

${ }_{3}$ Feralys Novauli, 'Pengaruh Kompetensi Guru Terhadap Peningkatan Prestasi Belajar Pada SMP Negeri Di Kota Banda Aceh', 6.1 (2012), 17-32 <https://doi.org/10.13170/jp.6.1.2026>.
} 
menjalankan proses pembelajarannya. Sesuai dengan penelitian dari ${ }^{4}$ yang mengemukakan bahwa bahwa kompetensi guru berpengaruh secara langsung positif terhadap prestasi belajar mata pelajaran ekonomi sebesar 40,9\%. Selain itu ${ }^{5}$ juga menegaskan bahwa variable kompetensi guru berpengaruh positif dan signifikan terhadap prestasi belajar siswa di MA DDI Kabupaten Bone.

Berdasarkan beberapa penelitian yang relevan di atas penulis melakukan penelitian di SMA Muhammadiyah 1 Taman dikarenakan prestasi belajar siswanya belum maksimal sehingga perlu adanya peningkatan kompetensi tenaga pendidik yang ada di sekolah tersebut. Hal tersebut terlihat dari nilai rata-rata paralalel siswa kelas XI dan XII nya memiliki persentase nilai di bawah nilai rata keseluruhan, hanya kelas X nya yang lebih banyak siswa di atas nilai rata-rata paralel sebagaimana dapat dilihat pada tabel 1.

Tabel 1. Nilai rata- rata paralel Kelas X - XII semester Ganjil Tahun Pelajaran $2019 / 2020$

\begin{tabular}{|c|c|c|c|c|c|c|}
\hline \multirow{2}{*}{ Kriteria } & \multicolumn{2}{|c|}{$\begin{array}{c}\text { Nilai Rata-rata } \\
\text { Paralel Kelas X }\end{array}$} & \multicolumn{2}{c|}{$\begin{array}{c}\text { Nilai Rata-rata } \\
\text { Paralel Kelas XI }\end{array}$} & \multicolumn{2}{c|}{$\begin{array}{c}\text { Nilai Rata-rata } \\
\text { Paralel Kelas XII }\end{array}$} \\
\cline { 2 - 7 } & \multicolumn{2}{|c|}{$\mathbf{8 0 , 4 1}$} & \multicolumn{2}{|c|}{$\mathbf{8 1 , 9 6}$} & \multicolumn{2}{c|}{$\mathbf{8 4 , 5 3}$} \\
\cline { 2 - 7 } & Jumlah & Presentase & Jumlah & Presentase & Jumlah & Presentase \\
bawah & 84 & $41,9 \%$ & 157 & $56,0 \%$ & 92 & $53,4 \%$ \\
\hline Di atas & 153 & $58,1 \%$ & 110 & $44,0 \%$ & 70 & $46,6 \%$ \\
\hline Total & 237 & $100 \%$ & 277 & $100 \%$ & 162 & $100 \%$ \\
\hline
\end{tabular}

${ }^{4}$ Inayah (2013)

${ }^{5}$ Hasanuddin (2017) 
Sekolah menilai kondisi tersebut perlu diperbaiki dan berharap nilai rata-rata siswa secara keseluruhan bisa lebih ditingkatkan lagi supaya sebaran rentang nilainya tidak terlalu besar. Oleh karena itu, SMA Muhammadiyah 1 Taman secara rutin memantau dan meningkatkan kompetensi tenaga pendidiknya. Sejalan dengan hal tersebut penelitian ini bertujuan untuk mendeskripsikan pengaruh peningkatan kompetensi tenaga pendidik terhadap prestasi belajar siswa di SMA Muhammadiyah 1 Taman.

\section{METODE PENELITIAN}

Penelitian ini menggunakan metode kualitatif dengan pendekatan fenomenologi. Penelitian kualitatif dirasa tepat untuk menjadi metodenya karena penelitian ini berusaha untuk memecahakan masalah menggunakan data empiris yang bisa dideskripsikan. Sedangkan pendekatan fenomenologi digunakan karena penelitian ini melakukan pendekatan terhadap objek penelitiannya berdasarkan fenomena yang terjadi tanpa menggunakan asumsi, praduga, prasangka ataupun konsep ${ }^{6}$. Metode pengumpulan data dilakuksan melalui observasi lapangan, wawancara kepada kepala sekolah dan tenaga pendidik yang ada serta dokumentasi yang berkaitan dengan peningkatan kompetensi tenaga pendidik di SMA Muhamamdiyan 1 Taman.

\section{HASIL DAN PEMBAHASAN}

Kompetensi tenaga pendidik sangat penting dalam rangka membentuk perilaku dan prestasi belajar yang baik bagi peserta didiknya. Hal tersebut dikarenakan siswa akan senantiasa mencontoh atau meniru tindakan-tindakan yang dilakukan oleh tenaga pendidik tersebut. Hal ini sesuai dengan firman Allah swt. dalam Q.S. AlAhzab: 21 yang menekankan bahwa seorang pendidik bukan hanya perlu

6 Jozef Raco, 'Metode Penelitian Kualitatif: Jenis, Karakteristik Dan Keunggulannya', 2018 $<$ https://doi.org/10.31219/osf.io/mfzuj > . 
menyampaikan materi pelajaran, melainkan harus menjadi menjadi teladan yang baik bagi siswanya ${ }^{7}$.

Tenaga pendidik diharapkan mampu menguasai berbagai peran untuk bisa mengarahkan peserta didiknya mencapai tujuan belajar yang diinginkan baik berupa prestasi belajar, pengembangan potensi atau keterampilan maupun pembentukan perilaku yang baik. Terdapat 13 peran yang perlu difahami dan dikuasai oleh tenaga pendidik dapat diuraikan sebagai berikut ${ }^{8}$ :

1. Korektor, tenaga pendidik harus memiliki kemampuan mengkoreksi sikap dan sifat anak didiknya.

2. Inspirator, tenaga pendidik harus bisa memberikan inspirasi yang baik bagi anak didiknya untuk bisa memajukan prestasi belajarnya atau merah impiannya.

3. Informator, tenaga pendidik perlu menjadi penyamapai pesan atau informasi yang benar supaya anak didiknya mampu membedakan mana informasi hoax dan mana informasi yang terpercaya.

4. Organisator, tenaga pendidik harus mampu menyesuiakan jadwal yang tepat, berkolaborasi dengan siswa maupun dengan sesame pendidik.

5. Motivator, tenaga pendidik harus mampu mendorong semangat dan keaktifan anak didiknya.

6. Inisiator, tenaga pendidik perlu menjadi pencetus ide-ide kemajuan dalam pendidikan dan pembelajaran anak didiknya seperti memanfaatkan kemajuan tknologi dalam proses pembelajarannya.

7. Fasilitator, tenaga pendidik hendaknya dapat menyesuaiakan fasilitas yang memungkinkan kemudahan kegiatan belajar anak didik.

8. Pembimbing, tenaga pendidk perlu menjadi seorang pembimbing yang baik dalam mengarahkan potensi dan pemecahan masalah dari anak didiknya karena tanpa bimbingan yang baik maka anak didik akan mengalami kesulitan dalam menghadapi perkembangan dirinya.

\footnotetext{
7 Departemen Agama RI, Alquran Dan Terjemahannya (Surabaya: Duta Ilmu, 2002).

${ }^{8}$ Syaiful Bahri Djamarah, Guru Dan Anak Didik Dalam Interaksi Edukatif (Jakarta: PT. Rineka Cipta, 2000).
} 
9. Demonstrator, tenaga pendidik perlu menjadi seorang pendemo yang menarik supaya tujuan pembelajaran yang diinginkan bisa sejalan dengan pemahaman anak didiknya

10. Pengelola kelas, tenaga pendidik hendak dapat mengelola kelas dengan baik, karena kelas adalah tempat perhimpunan semua anak didik dan tenaga pendidik dalam rangka menerima bahan pelajaran dari tenaga pendidik.

11. Mediator, tenaga pendidik hendaknya memiliki pengetahuan dan pemahaman yang cukup tentang media pendidikan dalam berbagai bentuk dan jenisnya, baik media nonmaterial maupun materil.

12. supervisor, tenaga pendidik hendaknya dapat membantu, memperbaiki, dan menilai secara kritis terhadap proses pengajaran.

13. Evaluator, tenaga pendidik perlu menyeimbangkan anatar penilaian hasil pembelajaran dengan penilaian proses pembelajaran supaya dapat memebrikan umpan balik (feedback) yang sesuai.

SMA Muhamamdiyah 1 Taman sebagai salah satu sekolah berbasis Islam yang ada di kota Sidoarjo memiliki visi misi berupa Sholeh Dalam Perilaku,Unggul Dalam Mutu dan Berdaya Saing Global yang diwujudkan dalam tiga pilar utama yaitu excellent academic quality, excellent Islamic character and global insight ${ }^{9}$. Sejalan dengan visi misi tersebut maka pimpinan sekolah senantiasa melakukan pelatihan, pendampingan dan pengawasan terhadap peningkatan kompetensi tenaga pendidiknya. Beberapa bentuk peningkatan kompetensi tenaga pendidik yang ada di SMA Muhammadiyah 1 Taman dapat dilihat pada tabel 2 .

Tabel 1. Peningkatan Kompetensi Tenaga Pendidik di SMA Muhamamdiyah 1 Taman

\begin{tabular}{|c|l|l|}
\hline No & Kompetensi & \multicolumn{1}{|c|}{ Bentuk Pelatihan/Pendampingan/Pengawasan } \\
\hline 1 & Pedagogik & $\begin{array}{r}\text { Mengadakan supervisi pembelajaran dimana setiap tenaga pendidik } \\
\text { akan di supervisi atau dimonitoring proses pembelajarannya secara } \\
\text { berkala. Supervisi dilakukan oleh kepala sekolah atau wakil kepala }\end{array}$ \\
& & \\
\hline
\end{tabular}

${ }^{9}$ Smamita, 'Visi Misi SMA Muhamamdiyah 1 Taman', Smamita.Ac.Id, 2018. 


\begin{tabular}{|c|c|c|}
\hline & & $\begin{array}{l}\text { sekolah bagian kurikulum } \\
\text { - Mengadakan pelatihan dan pendampingan pembuatan soal dan } \\
\text { penilaiannya menggunakan ujian berbasis komputer atau } \\
\text { smartphone } \\
\text { - Mengadakan pelatihan dan pendampingan pembelajaran blended } \\
\text { learning supaya pembelajaran yang dilakukan oleh tenaga pendidik } \\
\text { bisa mengintegrasikan pembelajaran konvensional dengan } \\
\text { pembelajaran berbasis teknologi informasi yang memanfaatkan } \\
\text { jaringan internet serta alat digital yang dimili oleh masing-masing } \\
\text { siswa }\end{array}$ \\
\hline 2 & Kepribadian & $\begin{array}{l}\text { - Mewajibkan tenaga pendidik untuk iku serta melaksanakan sholat } \\
\text { dhuha, sholat dhuhur dan sholat ashar berjamaah supaya bisa } \\
\text { menjadi teladan bagi siswa dalam pembentukan karakter islami } \\
\text { - Melatih setiap tenaga pendidik untuk saling memberi nasihat } \\
\text { kebaikan melalui kegiatan kultum (kuliah tujuh menit) pada setiap } \\
\text { pertemuan/rapat dewan guru dengan pimpinan sekolah } \\
\text { - Mengadakan pengawasan secara berkala terhadap komunikasi wali } \\
\text { kelas dengan setiap siswa di kelasnya maupun wali siswanya. Hal ini } \\
\text { dimaksudkan untuk melatih rasa empati dan tanggung jawab tenaga } \\
\text { pendidik terhadap siswa-siswinya. }\end{array}$ \\
\hline 3 & Profesional & $\begin{array}{l}\text { - Mengadakan dan memfasilitasi kegiatan musyawarah guru mata } \\
\text { pelajaran (MGMP) internal dan eksternal secara berkala. MGMP } \\
\text { internal merupakan forum musyawarah guru mata pelajaran yang } \\
\text { sama di satu sekolah sedangkan mgmp eksternal merupakan upaya } \\
\text { sekolah untuk mengikutsertakan guru mata pelajarannya untuk ikut } \\
\text { dalam mgmp se kabupaten sidoarjo maupun Jawa Timur. } \\
\text { - Mengadakan pelatihan dan pendampingan media pembelajaran atau } \\
\text { metode pmbelajaran yang menarik dan menyenangkan bagi semua } \\
\text { tenaga pendidik }\end{array}$ \\
\hline
\end{tabular}




\begin{tabular}{|l|l|l|}
\hline & Sosial & Mengadakan briefing atau rapat persiapan pembelajaran secara rutin \\
untuk melatih komunikasi dan menyamakan pemahaman sebelum \\
berinteraksi dengan siswa \\
- Membangun kerjasama tim antar tenaga pendidik dengan \\
mengadakan kegiatan-kegiatan kompetitif atau kegiatan sosial yang \\
bermanfaat bagi siswa maupun masyarakat sekitar \\
- Mengadakan pertemuan secara langsung dengan wali siswa melalui \\
forum parenting secara berkala ataupun komunikasi melalui media \\
sosial tentang perkembangan hasil belajar dan sikap dari putra \\
putrinya. \\
Mengadakan layanan konseling atau bimbingan rutin sesuai \\
kebutuhan siswa untuk menjadi sarana interaksi positif anatara \\
siswa dengan tenaga pendidik.
\end{tabular}

Berbagai kegiatan yang dilakukan oleh SMA Muhamamdiyah 1 Taman untuk meningkatkan kompetensi tenaga pendidik sejalan dengan arahan dari pemerintah. Sebagaimana tertuang dalam Peraturan Pemerintah Republik Indonesia Nomor 19 Tahun 2017 yang mengamanatkan bahwa guru sebagai tenaga pendidik harus memiliki kompetensi pedagogik, kompetensi kepribadian, kompetensi sosial, dan kompetensi professional yang menjadi suatu kesatuan sebagai ciri guru profesional ${ }^{10}$.

Berkaitan dengan pengaruhnya terhadap prestasi siswa didapatkan hasil penelitian pada semester genap tahun ajaran 2019/2020 dimana sebagian besar siswa mengalami peningkatan prestasi belajar seiring dengan meningkatnya kompetensi guru. Prestasi belajar siswa yang nilainya di atas nilai rata-rata di kelas X meningkat sebanyak 7\%, kelas XI meningkat sebanyak 12\% dan kelas XII meningkat sebanyak $11 \%$ sebagaimana dapat dilihat pada grafik 1.

10 Peraturan Pemerintah RI, Peraturan Pemerintab Republik Indonesia Nomor 19 Tabun 2017 Tentang Perubaban Atas Peraturan Pemerintab Nomor 74 Tabun 2008 Tentang Guru, MENTERI HUKUM DAN HAK AS ASI MANUSLA RI (Jakarta, 2017). 


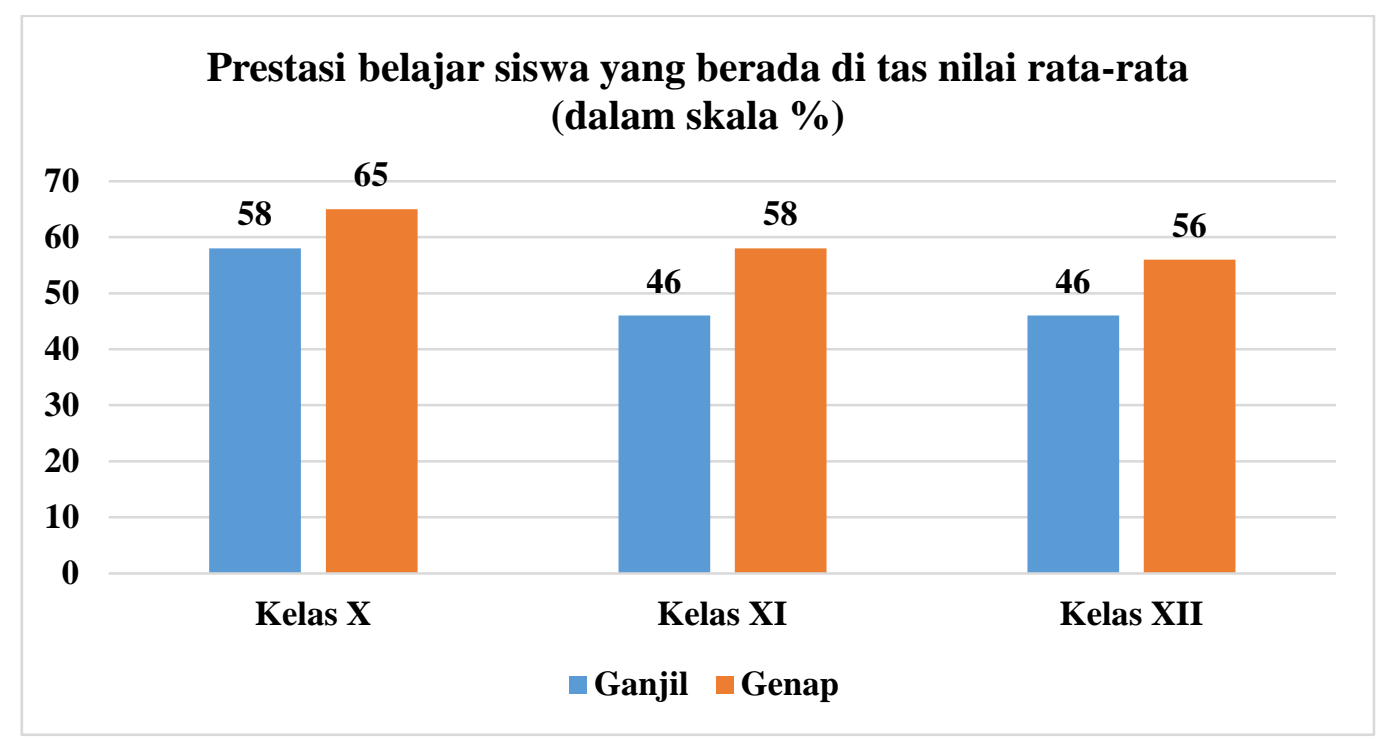

Peningkatan prestasi belajar siswa di atas berkatan erat dengan peningkatan kompetensi tenaga pendidik, hal tersebut dikarenakan adanya kepedulian dari tenaga pendidik berupa semangat untuk meningkatkan prestasi belajar siswa baik pada aspek kognitif, aspek afektif dan psikomotorik akan sangat mempengaruhi prestasi belajar siswa. Dalam hal ini tidak bisa dilepaskan peran dari sekolah untuk meningkatan profesionalisme guru dalam bentuk pelatihan, pendampingan serta pemberian reward atau penghargaan berupa gaji dan fasilitas yang memadai ${ }^{11}$.

\section{KESIMPULAN}

Peningkatan kompetensi tenaga pendidik berkaitan erat dengan peningkatan prestasi belajar siswa hal tersebut dikarenakan terdapat faktor internal dan faktor ekesternal yang mempengaruhi prestasi belajar siswa. Salah satu faktor eksternal yang sangat berperan dalam peningkatan hasil belajar siswa adalah kompetensi tenag pendidik yang berkualitas baik dari kompetensi pedagogik, kompetensi kepribadian, kompetensi sosial dan kompeteni profesional. Peningkatan kompetensi tenaga pendidik juga tidak bisa dilepaskan dari peran sekolah sebagai lembaga pendidikan

11 Heronimus Delu Pingge, 'Faktor Yang Mempengaruhi Hasil Belajar Siswa Sekolah Dasar Di Kecamatan Kota Tambolaka', JPSD :Jurnal Pendidikan Sekolah Dasar Vol. 2, No. 1 Desember, 2.1 (2016), 20 . 
untuk memberikan pelatihan, pendamingan dan pengawasan terhadap peningkatan kompetensi tenaga pendidik.

\section{DAFTAR PUSTAKA}

Asrul, Rusydi Ananda, and Rosinta, Evaluasi Pembajalaran, Ciptapustaka Media, 2014

Departemen Agama RI, Alquran Dan Terjemahannya (Surabaya: Duta Ilmu, 2002)

Djamarah, Syaiful Bahri, Guru Dan Anak Didik Dalam Interaksi Edukatif (Jakarta: PT. Rineka Cipta, 2000)

Hapnita, Widia, 'Faktor Internal Dan Eksternal Yang Dominan Mempengaruhi Hasil Belajar Menggambar Dengan Perangkat Lunak Siswa Kelas Xi Teknik Gambar Bangunan Smk N 1 Padang Tahun 2016/2017', CIVED (Journal of Civil Engineering and Vocational Education), $5.1 \quad$ (2018) $<$ https://doi.org/10.24036/cived.v5i1.9941>

Hasanuddin, Sultan, 'Pengaruh Kompetensi Guru Terhadap Prestasi Belajar Siswa Pada Mata Pelajaran Sejarah Kebudayaan Islam Di MA DDI Ponre Kabupaten Bone Sultan Hasanuddin', 16.1 (2017), 146-61

Inayah, R, 'Pengaruh Kompetensi Guru, Motivasi Belajar Siswa, Dan Fasilitas Belajar Terhadap Prestasi Belajar Mata Pelajaran Ekonomi Pada Siswa Kelas XI IPS SMA Negeri 1', Jurnal Pendidikan Insan Mandiri, 2013, 1-13

Novauli, Feralys, 'Pengaruh Kompetensi Guru Terhadap Peningkatan Prestasi Belajar Pada SMP Negeri Di Kota Banda Aceh', 6.1 (2012), 17-32 $<$ https://doi.org/10.13170/jp.6.1.2026>

Peraturan Pemerintah RI, Peraturan Pemerintab Republik Indonesia Nomor 19 Tabun 2017 Tentang Perubahan Atas Peraturan Pemerintab Nomor 74 Tabun 2008 Tentang Guru, MENTERI HUKUM DAN HAK AS ASI MANUSLA RI (Jakarta, 2017)

Pingge, Heronimus Delu, 'Faktor Yang Mempengaruhi Hasil Belajar Siswa Sekolah Dasar Di Kecamatan Kota Tambolaka', JPSD :Jurnal Pendidikan Sekolah Dasar Vol. 2, No. 1 Desember, 2.1 (2016), 20

Raco, Jozef, 'Metode Penelitian Kualitatif: Jenis, Karakteristik Dan Keunggulannya', 2018 <https://doi.org/10.31219/osf.io/mfzuj>

Smamita, 'Visi Misi SMA Muhamamdiyah 1 Taman', Smamita.Ac.Id, 2018 